\title{
Visualizando lo invisible. Las redes de misioneros y probabilistas en el siglo XVI y primeros años del XVI I
}

\author{
Laura Leticia Mayer Celis ${ }^{\mathbf{1}}$ \\ Alejandro Arnulfo Ruiz León \\ Universidad Nacional Autónoma de México, México
}

\begin{abstract}
Resumen
En este trabajo el modelo de red se usa como aproximación metodológica para comprender una realidad social: la circulación de personajes y conocimientos en el siglo XVI y principios del XVII. La hipótesis que guía esta reflexión es que el contacto de los misioneros con la otredad introdujo en el pensamiento teológico europeo el sentido de incertidumbre y riesgo moral, que dio origen a una escuela de pensamiento llamada "probabilismo", antecedentes de las ideas de probabilidad ${ }^{2}$. El descubrimiento de América fue para Europa un encuentro con lo verdaderamente desconocido, con el Otro. Los primeros misioneros en Nueva España abrieron los procesos de incertidumbre y las preguntas ante la otredad. Las misiones en Oriente asimilaron el tamiz de las discusiones misioneras en América para adaptarse a las culturas de los otros. Efectivamente, la idea de probabilidad - tan importante para la ciencia actual- es multicausal, como la mayoría de las grandes corrientes de pensamiento, y en este es necesario recurrir a un contexto sociocultural muy particular: lo que sucedió en el siglo $\mathrm{XVI}$ con la expansión europea, tanto al continente americano como al lejano Oriente. EI problema de enfrentar, juzgar y convivir con el Otro.
\end{abstract}

Palabras claves: Redes - Misiones - Probabilismo - Otredad

\section{Abstract}

The network model is used as a methodological approach to understand social reality: the circulation of characters and knowledge in the XVI century and in the beginning of XVII century. The hypothesis that enlightens this reflection is that the contact of the missioners with the otherness introduces in the European theological thought the sense of uncertainty and moral risk, which brought out a school of thought named "probabilism"; antecedents of ideas of probability. To Europe the discovery of America was an encounter with the complete unknown with the otherness. The first missioners in New Spain opened the uncertainty processes and the questions about the otherness. The eastern missions assimilated the sieve of the missioner discussions in America to be able to adapt to the cultures of the otherness. The idea of probability; with such an importance in science in our days, is certainly multicasual as most of the major

1 Contacto: Laura Leticia Mayer Celis. Universidad Nacional Autónoma de México. Dirección electrónica: IImc95@gmail.com

2 Mayer, 2011. 
currents of thought, and as such, it is necessary to appeal to a very particular sociocultural context: what happened during the XVI century when Europe expanded to the American continent as well as to the far East. The problem of facing, judging and living with the otherness.

Key words: Networks - Missions - Probabilism - Otherness.

\section{Introducción}

En este trabajo mostramos la utilidad de la metodología del análisis de las redes sociales para visualizar los contactos y escuelas de pensamiento en que se desarrollaron las primeras misiones en América y Oriente. El análisis de la circulación de personajes y conocimiento, así como como la determinación de contactos esta basado en un trabajo histórico.

A través de las redes sociales, y su representación gráfica, podemos introducirnos en los espacios informales, en este caso las escuelas de pensamiento, la circulación de saberes y su influencia en los diversos personajes. Las imágenes que se presentan son más bien huellas de interacciones, que discursos fuertemente integrados. Son redes de contacto o de influencia de conocimientos que van más allá de los marcos institucionales. Es seguir personajes que se movieron, por primera vez, en un mundo globalizado. Las redes se utilizan dentro de un marco de investigación más amplio, pero que nos sirven como herramientas para encontrar espacios y procesos en el tiempo que de otra forma difícilmente podrían visualizarse.

El modelo de red lo usamos como aproximación metodológica pertinente para comprender una realidad social: la circulación de personajes y conocimientos en el siglo XVI y principios del XVII. Las redes permiten comprender y seguir el relato histórico, a través de ellas podemos ver que no hay una linealidad histórica, sino que el intercambio se mueve en diferentes planos y con actores que van apareciendo en diversos momentos, por lo que los emplazamientos y desplazamientos en el campo social están en una perpetua recomposición. ${ }^{3}$

Los lazos que unen una red no son siempre iguales; algunos son contactos directos y de larga duración, otros son influencias intelectuales o bien pueden ser interacciones o contactos que aparentan ser efímeros pero que tejen relaciones que algunas veces son

\footnotetext{
${ }^{3}$ Rosé, Isabel, 2011, p. 147.
} 
más importantes de lo que parecen ser. La suma de todas estas interacciones es lo que vuelve dinámica y con movimiento la red de actores.

\section{Contexto histórico e hipótesis}

La hipótesis que guía esta reflexión es que el contacto de los misioneros con la otredad, al descubrir las nuevas rutas marítimas y enfrentarse a culturas totalmente diferentes a la occidental, introdujo en el pensamiento teológico europeo el sentido de incertidumbre y riesgo moral que dio origen a una escuela de pensamiento llamada "probabilismo".

El probabilismo es una corriente dentro de la filosofía moral del cristianismo que se desarrolló a partir del siglo XVI. Dentro del probabilismo se acepta una opinión "probable" o emitida por una autoridad "proba". En contraposición, se encuentra el probabiliorismo, la corriente que solo acepta las escrituras y lo aseverado por los padres de la Iglesia, la llamada Patrística. Dentro de esta corriente ha sido particularmente importante la opinión de San Agustín (354-430).

Una característica central del probabilismo es que en él las certezas son imposibles. Además de que esta corriente se configuró como un sistema basado, tanto en fundamentos razonables como en el estudio de casos concretos - la casuística- para entender problemas que se encontraban en el campo de la moral, esta teoría abrió una ranura en el determinismo y permitió el desarrollo de la duda, la incertidumbre y el riesgo moral.

Podemos suponer que el probabilismo se inició en la Universidad de Salamanca, principalmente por las discusiones teológicas de los dominicos, con autores como Francisco de Vitoria (1482/86-1546). Posteriormente, la orden más ligada al probabilismo fue la Compañía de Jesús con el desarrollo de la casuística moral, particularmente de las propuestas filosóficas de Luis de Molina (1535-1600) y Francisco Suárez (1548-1617).

Planteamos que el probabilismo fue creando significados a la duda moral que se desarrolló, principalmente, cuando Europa tuvo que afrontar la existencia del Otro. Esto sucedió en el siglo XVI con la expansión europea, tanto al continente americano como al lejano Oriente. El problema de enfrentar, juzgar y convivir con el Otro se dio en muchos grupos diferentes como los comerciantes que tuvieron contactos con 
culturas lejanas a la europea. Sin embargo, en las misiones se generó una discusión que marcó algunos de los paradigmas de Occidente. Junto con Corsi, ${ }^{4}$ consideramos a las misiones como el lugar privilegiado del encuentro con el Otro. En ellas se materializaron las tensiones entre centro y periferia, además de la producción y circulación de conocimientos ortodoxos y ajenos. Por otra parte, las misiones dejaron una amplia documentación que incluye maravillosas descripciones de pueblos y territorios desconocidos para los europeos, así como discusiones teológicas morales que nos conectan con diferentes elementos históricos, algunos poco explorados.

Las preguntas que rondan este trabajo son: ¿Puede ligarse el probabilismo a las misiones? ¿La duda, la falta de certidumbre moral se planteó cuando se enfrentaron a culturas totalmente diferentes a la mediterránea?

Como veremos a lo largo de este trabajo, el probabilismo fue creado por las discusiones de los dominicos, particularmente los de la Universidad de Salamanca, que tuvieron estrecho contacto con las noticias y personajes que llegaban de América. En el gráfico 1 se muestra la red de misioneros y de personajes que tuvieron contacto en el inicio del probabilismo en la Universidad de Salamanca.

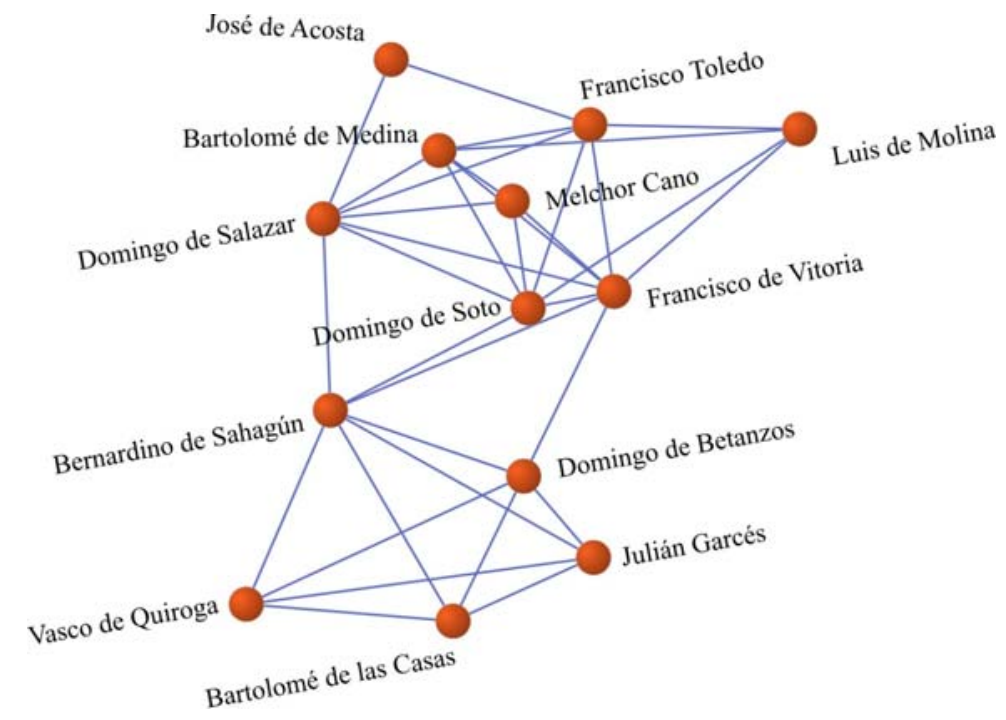

Gráfico 1. Red de la Universidad de Salamanca.

\footnotetext{
${ }^{4}$ Corsi, 2008.
} 
En el siglo XXI, con la expansión e imposición de la cultura occidental, nos es difícil aceptar que puede haber más de una racionalidad, pero este fue uno de los principales problemas que tuvieron que encarar los misioneros, tanto en América como en el lejano Oriente.

El encuentro de los europeos con culturas tan ajenas como fueron las americanas o las del lejano Oriente, seguramente provocó una serie de reacciones diferentes, algunas inmediatas y de poco alcance y otras mucho más profundas y que marcaron tendencias evolutivas mundiales. Podemos suponer que el Otro produjo rechazo, miedo, represión, pero también, como veremos a lo largo de este artículo, produjo desconcierto, dudas y un replanteamiento de la propia cultura occidental. Planteamos que el probabilismo se desarrollo en esta vertiente del encuentro con el Otro.

Al igual que Lisón Tolosana, nos atrevemos a decir que lo que los misioneros "escribieron es tan relevante hoy como ayer y [...] ellos nos dan ejemplo de cómo acercarnos al Otro". ${ }^{5}$ En este sentido es que desarrollamos este trabajo desde una historiografía antropologizada.

La expansión de Europa y el papel de las misiones en tierras lejanas al mediterráneo nos lleva a un problema central: el contacto intercultural y las relaciones entre América, Asia y Europa. Elementos significativos de la cultura mediterránea y que se discutieron durante mucho tiempo, se dieron en tierras y culturas lejanas a la europea. En este sentido el probabilismo replantea la discusión de lo que ha dado en llamarse centro-periferia.

\section{Las misiones externas: un problema fuera de Europa}

Antes del siglo XVI, en vez de la palabra misión, se utilizaban términos como "plantar la fe", "anunciar la buena nueva" o "promulgar el evangelio". ${ }^{6}$ Durante la Edad Media, el clero regular favoreció los viajes a lugares lejanos, de hecho se conocieron como peregrinaciones y esta noción se mezcló con la idea de misión. No obstante, la misión,

\footnotetext{
${ }^{5}$ Lisón Tolosana, 2005, p. 6.

${ }^{6}$ Corsi, 2008, p. 25.
} 
particularmente a partir del siglo XVI, estuvo unida a la colonización, pues el derecho de poseer colonias implicaba el deber de evangelizar.

Pero la evangelización se vio de muy diversas formas. Como hemos dicho anteriormente, el probabilismo fue una de las corrientes que ayudó a entender a los seres humanos que se desarrollaron en culturas diferentes a la europea. En otros casos, a fenómenos similares, se les llamó "acomodación". Este fue un método misional de adaptación del cristianismo que utilizaron de manera particular los jesuitas, aunque también lo emplearon franciscanos, dominicos y agustinos.

El accomodatio fue usado por los misioneros como dispositivo hermenéutico para estudiar las religiones locales y hallar en ellas figuras de la revelación cristiana. Pero bajo el mismo término, accomodatio, también se entiende la actitud de algunos misioneros que consistió en el estudio de las lenguas nativas, en la adopción de modales, reglas de convivencia, vestimenta, hábitos alimenticios propios de la clase de los letrados en China, en Japón y de los brahmanes en Asia meridional, con los cuales los jesuitas se identificaron. ${ }^{7}$

Un misionero en Macao, el padre Pedro Gómez, escribió lo siguiente al general de la Compañía, Claudio Acquaviva (1543-1615):

“Casi llego a los cincuenta años de edad y confieso a su Paternidad que estoy aprendiendo todo otra vez, como si estuviera entrando al mundo: estoy aprendiendo a comer, a beber, a sentarme, a acostarme, a vestirme, a ponerme los zapatos, a recibir y a ser recibido; aprendiendo las cortesías, el alfabeto, el lenguaje y la vida. Espero que le agrade al Señor que yo me convierta en un niño en nombre de su amor quien, siendo la sabiduría de la tierra, por mi bien se convirtió en un niño incapaz de hablar. Según mi entendimiento, quienes van a Japón también tienen que deshacerse de las costumbres y de los ropajes que traen de Europa y usar los ropajes y las nuevas costumbres del Japón, de modo que no [intentemos] transformar la naturaleza de los japoneses a imagen y semejanza de la nuestra, sino al contrario, a fin de acercarlos a nuestro espíritu y nuestra santa fe". ${ }^{8}$

\footnotetext{
${ }^{7}$ Corsi, 2008 p. 40. Desde la antropología, Aguirre Beltrán,1970 1 lo llamó proceso de aculturación.

${ }^{8}$ Citado por Corsi, 2008, pp. 40-41. Es una carta de fecha 5 de junio de 1582.
} 
Este principio de acomodación es parte de los planteamientos del probabilismo como corriente de apertura teológica a partir del siglo XVI. No obstante, Europa fue la protagonista implícita de los contactos entre Asia y América. Lo que nos permite ver la interconexión o red de contactos que empezó a perfilarse desde el siglo XVI, como resultado de un primer momento de globalización.

\section{Las misiones en América: la antesala de la incertidumbre ${ }^{9}$}

Este fenómeno es uno de los puntos de inflexión más interesantes de la historia de la humanidad. El descubrimiento de América, con la posterior conquista y colonización, fue para Europa un encuentro con lo verdaderamente desconocido, con el Otro. No se diga para los habitantes de América. Como es bien sabido, el contacto no solo implicó cambios culturales y sociales para ambos lados del Atlántico, sino también contactos biológicos como fueron las epidemias de viruela que diezmaron a la población americana. Es inevitable citar la conocida frase de Francisco López de Gómara (15111566) "el más grande evento desde la creación del mundo, aparte de la encarnación y muerte de aquel que lo creó".

Para Juan Luis Vives (1492-1540), quien observaba el crecimiento de las rutas comerciales, el contacto con América y el lejano Oriente, "Nos han descubierto rutas del cielo y del mar nunca conocidas hasta ahora, ni siquiera de oídas; pueblos y naciones admirables por sus costumbres y su barbarie." ${ }^{10}$ En el gráfico 2 se muestran las principales rutas comerciales de la época.

\footnotetext{
9 La problemática y las disputas sobre la conquista americana y su influencia sobre el pensamiento probabilista dan para escribir un libro completo. No obstante, en este trabajo, nos ceñiremos a los personajes más importantes e ideas más significativas.

${ }^{10}$ Citado por Bataillon, 1996, p. 817.
} 


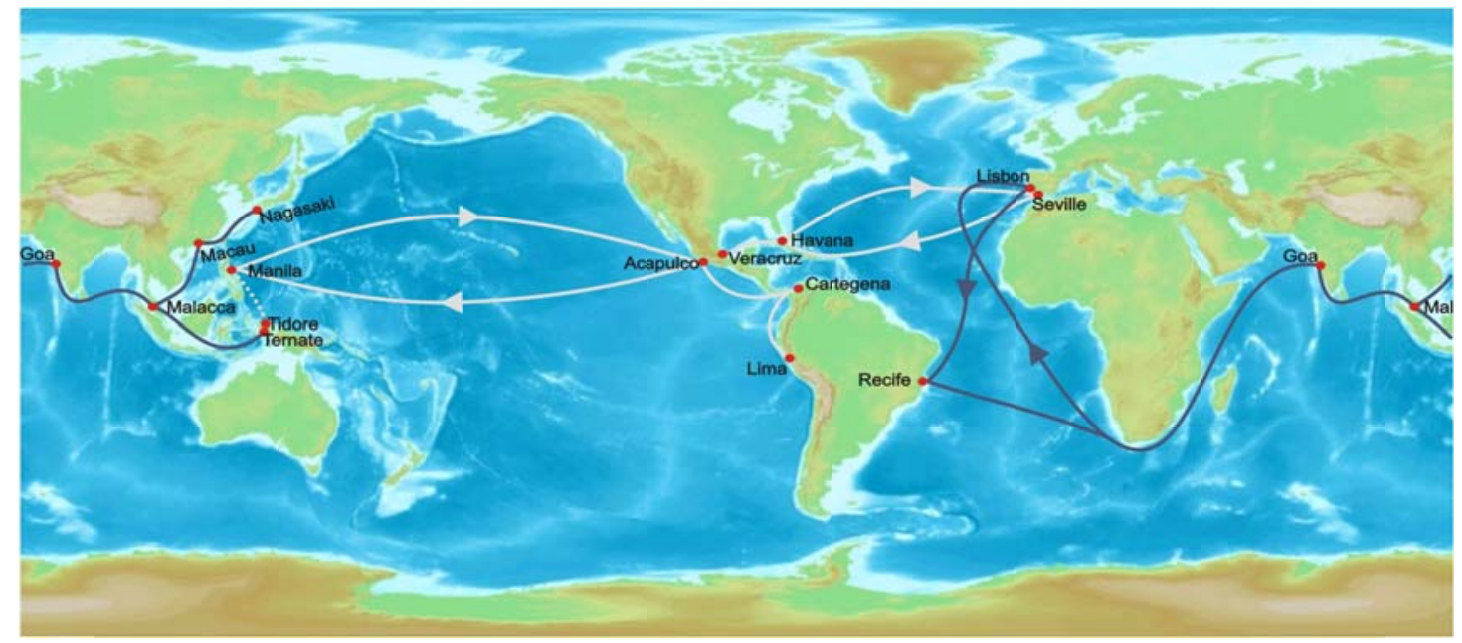

Fuente: elaboración propia.

Gráfico 2. Rutas marítimas.

La experiencia americana abrió los límites del mundo europeo al exponer un nuevo continente occidental. Esta experiencia vital quedó relativamente olvidada después de las guerras que España libró, particularmente contra Inglaterra, y que durante el siglo XVIII crearon una especie de "leyenda negra" y dejaron en el olvido el interés crucial de los escritos sobre las Indias Occidentales. Es necesario señalar que a partir del siglo XVII, España entró en un proceso de decadencia del que no se pudo recuperar en muchos años.

Sin embargo, en el momento de los descubrimientos y las conquistas, España vivía una etapa cosmopolita de su historia. Al mismo tiempo se estaban dando grandes debates en las universidades de Salamanca y Alcalá. En particular, la Universidad de Salamanca estaba viviendo un momento de esplendor. Las discusiones sobre el pensamiento jurídico, la moral, la economía, las propuestas sobre la guerra justa y los derechos de los no cristianos abrieron un debate de primer nivel que tuvo importantes repercusiones.

En España convivieron, con más o menos conflictos, importantes minorías moriscas, judíos conversos y católicos, aparentemente dominantes, que desempeñaron un papel muy importante en el pensamiento religioso y humanista. ${ }^{11}$

Ya en el siglo XX, se plantearon los escritos de los viajeros y primeros misioneros como los antecedentes de la Antropología Social, tanto por sus excelentes trabajos sobre

${ }^{11}$ Bernard, 1992, p. 19. 
América, como por las descripciones detalladas de las culturas que observaron. En estas obras podemos apreciar el impacto que la Otredad causó en los europeos: repugnancia por los sacrificios humanos y el canibalismo, rechazo a la homosexualidad y miedo ante lo desconocido, pero también admiración ante una cultura ajena y su organización social. En la comparación entre los habitantes del nuevo mundo y los europeos, estos últimos no siempre salieron bien librados. ${ }^{12}$

Además, el contacto América-Europa significó una problematización muy particular para la filosofía occidental, en especial en los planteamientos de derecho y justicia. En el caso de algunos de los primeros misioneros en la Nueva España como fueron: Juan de Zumárraga (1468-1548), Vasco de Quiroga (1470-1565), Bartolomé de las Casas (1474-1566) y Julián Garcés (1452-1546), la conquista implicó una verdadera disputa moral. Estos personajes son anteriores a los planteamientos del probabilismo y están fuertemente influenciados por el humanismo, particularmente el de Erasmo de Rotterdam (1466/69-1536). En el gráfico 3 se pueden observar los personajes relacionados con el probabilismo que tuvieron influencia del humanismo, particularmente de Earsmo de Rotterdam.

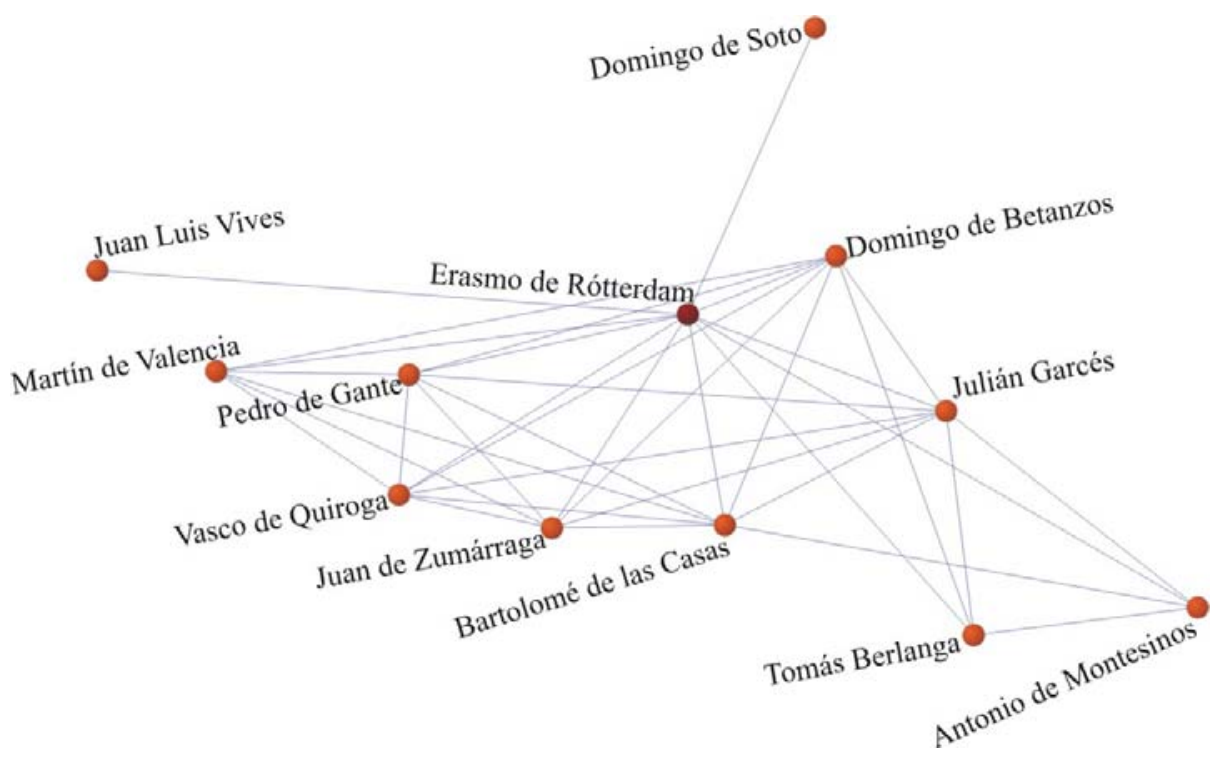

Gráfico 3. Red de influencia erasmista.

${ }^{12}$ Véase también Krotz, 2004, p. 183 y ss. 
En sus últimos trabajos, el de Rotterdam se interesó por la colonización del mundo occidental. En su obra sugirió que, al igual que hicieron los apóstoles con los primeros cristianos, a los que quitaron las cargas de la ley mosaica para evitar las resistencias, también en el siglo XVI podría "quitarse la obligación de ciertas cosas sin las cuales empezó a ser salvado el mundo, y podría aún hoy salvarse, con tal que hubiese fe y caridad evangélica". ${ }^{13}$ Mientras Erasmo escribía esto, en la Nueva España se desplegaba un pequeño ejército de misioneros, "Ios Doce Apóstoles" capitaneados por el franciscano Martín de Valencia ( $i$ ?-1534). Misioneros a quienes no escandalizaron los escritos erasmistas, además de que fueron mucho más que frailes reformadores. Poco después empezaron a llegar los obispos, hombres de gran formación y valor como el dominico Julián Garcés, el franciscano Juan de Zumárraga y Vasco de Quiroga. Estos religiosos tuvieron la intención de convertir al cristianismo a los naturales, sin echar a perder sus cualidades. Así, según Vasco de Quiroga, se fundó una “Iglesia Nueva y Primitiva", mientras que los cristianos de Europa se empeñaban, como decía Erasmo, en "meter un mundo en el cristianismo". ${ }^{14}$ En el gráfico 4 se muestra la red de contactos de 10 misioneros en que sólo Bernardino de Sahagún no tuvo influencia directa de Erasmo de Rotterdam y que junto a Vasco de Quiroga, Bartolomé de las Casas, Domingo de Betanzos y Julián Garcés se vieron involucrados en el incio del probabilismo.

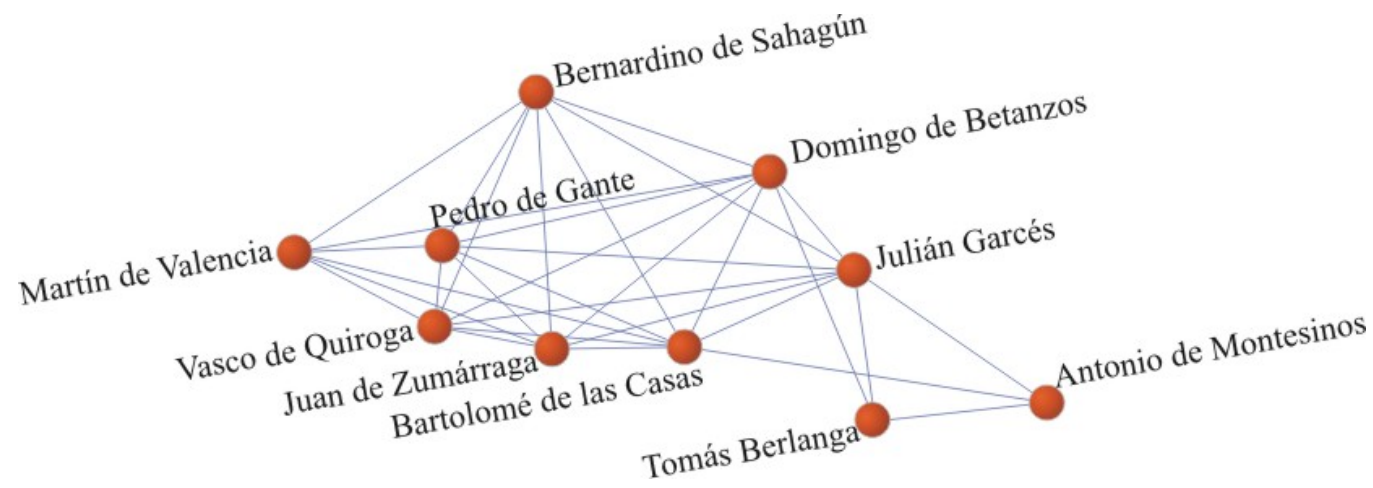

Gráfico 4. Red de misioneros en América. Primera mitad del siglo XVI.

\footnotetext{
${ }^{13}$ Citado por Bataillon, 1996, p. 817.

${ }^{14}$ Bataillon, 1996, p. 821.
} 


\section{El probabilismo: una discusión europea}

El término probabilismo, como hemos visto, fue tardío, comenzó a utilizarse a mediados del siglo XVI y se volvió de uso común entre moralistas en el siglo XVII. La Edad Media no conoció grandes debates respecto a la acción moral. ${ }^{15}$ En general, la teología se había enfocado más a las cuestiones dogmáticas, mientras que a los principios morales se les había dado menos importancia.

Aunque en el siglo XVI, las doctrinas tomistas dominaban el mundo de la educación y de la discusión moral, primero los dominicos y después los jesuitas encontraron que no tenían bastantes armas para enfrentar las corrientes protestantes $y$, particularmente, los problemas que presentaban las misiones fuera de Europa. ${ }^{16}$

Por su parte, el general de la Compañía de Jesús, Claudio Acquaviva, se enfrentó abiertamente al clero secular y afirmó que, aunque Santo Tomás de Aquino (12251274) era el autor más digno de loa, sería un yugo insoportable pretender seguirle en todas las materias al pie de la letra y no considerar otras opiniones. ${ }^{17}$ Acquaviva significó un cambio en la historia de la Compañía. Durante su largo mandato (15811615), los jesuitas enfrentaron las nuevas condiciones sociales, particularmente los años más activos de las misiones en Oriente. Acquaviva fue un político astuto, pero también planteó una reforma plena que apuntó al fortalecimiento de la espiritualidad individual, altamente preciada en el probabilismo. ${ }^{18}$

Con el dominico Bartolomé de Medina (1527-1581), profesor de Salamanca y el jesuita Francisco Suárez que enseñó en varias universidades en lugares como Roma, Alcalá,

\footnotetext{
${ }^{15}$ Delumeau, 1992, p. 111.

${ }^{16}$ Es curioso constatar que las opiniones sobre el dominio del tomismo, el fatalismo agustiniano o del probabilismo va a depender del autor del que se trate. Por ejemplo, Brockliss, 2002, p. 163, profesor de la Universidad de Oxford, afirma que la Europa del siglo XVII fue un mundo dominado por el pesimismo y la visión agustiniana de la predestinación y que solo hubo un puñado de hombres que siguieron al jesuita Molina. Por otra parte, como veremos más adelante, Delumeau, 1992, p. 117, historiador francés, afirma que las tesis probabilistas dominaron la enseñanza de la teología. Por supuesto que la primera es una visión inglesa y protestante de lo que fue Europa en aquella época. La segunda es la visión francesa y católica del mismo período, lo interesante es que ambos autores generalizan la visión a todo el continente.

${ }^{17}$ Ranke, 1993, p. 363.

${ }^{18}$ Pavone, 2007, p. 47.
} 
Salamanca y Coimbra, el probabilismo se volvió de uso común en la teología moral. En el gráfico 5 se muestra los contactos entre personajes más relevantes en la difusión del probabilismo, así como las cuatro instituciones más importantes en su enseñanza: la Universidad de Salamanca, la Universidade de Alcalá, la Universidad de Coimbra y el Colegio Romano. En la parte media hacia la derecha se localizan Bartolomé de Medina y Francisco Suárez.

Esta revolución moral consistió en la afirmación de que en caso de duda puede seguirse cualquier opinión que simplemente sea probable. A raíz de estas teorías se desarrolló la casuística. De los años 1564 a 1663 los autores católicos escribieron alrededor de seiscientos tratados de casuística. ${ }^{19}$ Esto deja ver el impacto que el probabilismo y las discusiones en torno a él tuvieron durante esta época.

Según Caro Baroja:

“El asunto cardinal es que cuando, como consecuencia última, se desarrolló la teoría probabilista, los profesores italianos, españoles, austriacos, franceses, etc., tuvieron que reconocer, una y otra vez, que el mundo de los penitentes era una selva". ${ }^{20}$

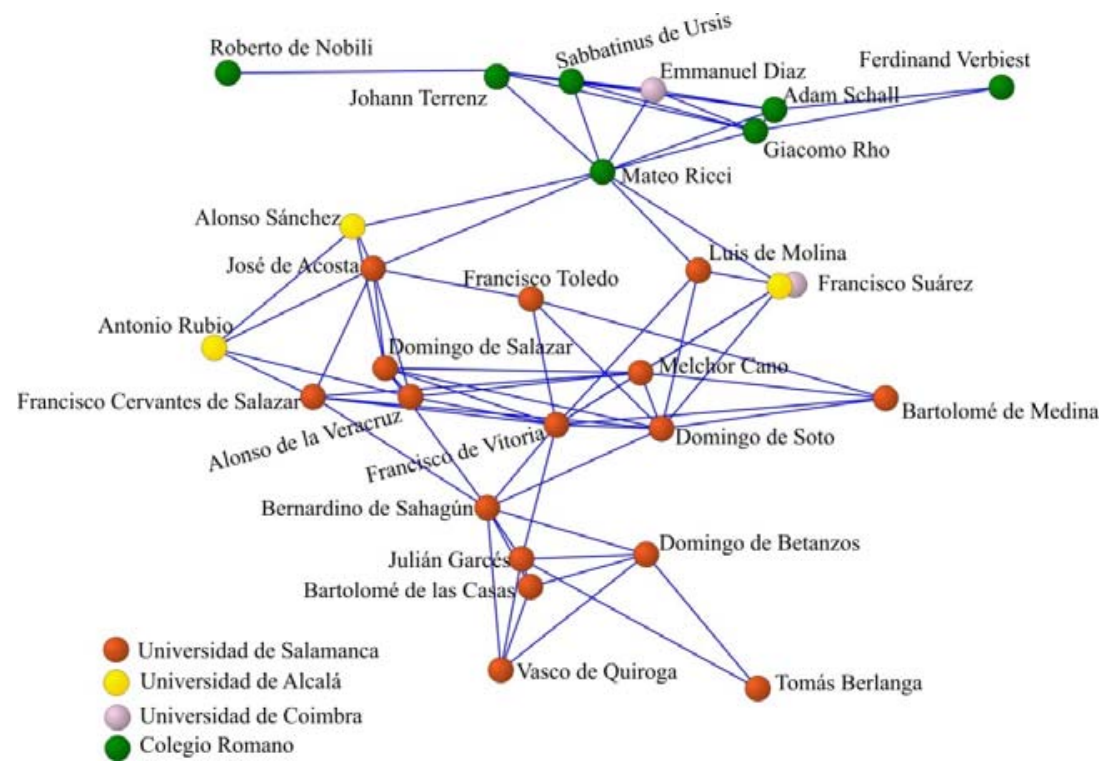

Gráfico 5. Red de universidades: Salamanca, Alcalá, Colegio Romano y Coimbra.

\footnotetext{
${ }^{19}$ Delumeau, 1992, pp. 117-118.

${ }^{20}$ Caro Baroja, 1978, pp. 523-524.
} 
Las largas discusiones sobre la guerra justa y el derecho de conquista fueron muy conocidas. Los informes y relaciones sobre el Nuevo Mundo que llegaron a España, procedentes de los autores antes mencionados, fueron el material factual que ayudó a la reflexión de los primeros probabilistas como: Francisco de Vitoria, Domingo de Soto (1494-1560) ${ }^{21}$ y Melchor Cano (1509-1560). En el gráfico 6 se muestra la red de contactos hacia el año de 1550 de misioneros en américa y probabilistas. Forman parte de ella tres misioneros inciadores del porbabilismo: Bernardino de Sahagún, Bartolomé de las Casas y Vasco de Quiroga.

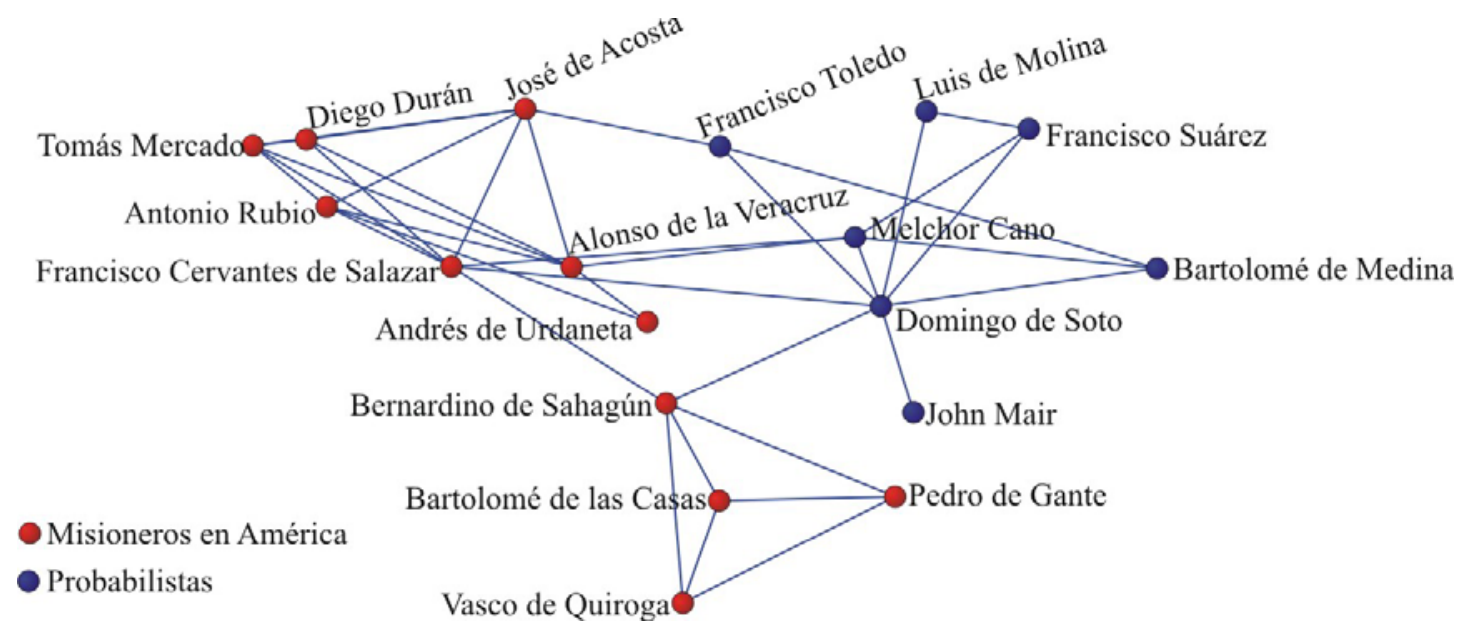

Gráfico 6. Red de misioneros en América y probabilistas en 1550.

Particularmente la conquista y sus discusiones sobre la guerra justa fueron una inspiración para Francisco de Vitoria. ${ }^{22}$ La influencia de éste en América fue muy grande, a pesar de que nunca salió de Europa; Vitoria no solo tuvo contacto con algunos de los misioneros que llegaron al Nuevo Mundo, sino que a través de su conocimiento de América y sus escritos y reflexiones sobre estas tierras, se le considera el padre del derecho internacional.

Vitoria estudió en París, pero hacia 1523 fue restituido al colegio de San Gregorio de Valladolid, ciudad que era frecuentada, en aquella época, por la corte imperial y el

\footnotetext{
${ }^{21}$ Este autor fue predecesor de Galileo y una fuerte influencia en los trabajos físicos del excelente naturalista. Véase Wallace, 2004.

22 Un contemporáneo de Vitoria, y su amigo, fue: John Mair (1469-1550), quien dio clases en la Universidad de París e hizo las primeras aportaciones sobre la guerra justa. Beuchot, 1991, pp. 125-142.
} 
Consejo de Indias, lo que seguramente lo puso en relación muy directa con los problemas indianos. Hacia 1526 ocupó la cátedra de prima en la Universidad de Salamanca. Mientras vivió en esa ciudad, su residencia estuvo en el convento de San Esteban, que probablemente fue uno de los mayores centros de recepción de documentos sobre América y noticias de personajes que venían de ella. El rey, Carlos I, tenía gran aprecio del filósofo, pues al leer las Relecciones de Vitoria se dio cuenta de que no negaba o se oponía férreamente a la conquista de América, como lo hizo fray Bartolomé de las Casas, sino que era un espíritu crítico de las prerrogativas del rey y del papa en el Nuevo Mundo. ${ }^{23}$ Vitoria también apoyó el derecho de los infieles a tener propiedades y facultad de gobierno sobre los estados nativos.

La guerra de conquista no fue fácil de justificar, pues no estaban peleando contra enemigos que les habían causado daño, como los sarracenos, sino contra nativos con los que jamás habían tenido contacto. Siguiendo el derecho divino, Vitoria afirma que las sociedades americanas están dentro del derecho natural, lo que en última instancia es de origen divino, por lo que la propiedad, los príncipes y los señores de estas tierras son tan legítimos como los europeos. ${ }^{24}$

No obstante es conveniente no descontextualizar los trabajos de Vitoria. Este autor representa los principios de la duda ante el Otro. Sin embargo, su forma de conocimiento está todavía basada en el principio de autoridad. En sus trabajos se expone la problemática y la argumentación que, en gran medida, está basada en las escrituras y las autoridades. Por ejemplo, en su primera relección: De los indios recientemente descubiertos, Vitoria dice:

“En materia dudosa, después de consultar el caso de los doctos deciden ser lícita una cosa que, por otra parte, es ilícita, si se debe para la seguridad de conciencia seguir el parece de aquellos. [...] que aunque lo principal y más importante de la cuestión esté suficientemente examinado y comprobado, ¿acaso no pueden, en asunto tan grande, ocurrir algunas dudas particulares que merezcan dilucidarse?" 25

\footnotetext{
${ }^{23}$ Gómez Robledo, “Introducción”, 2007, p. XIX.

${ }^{24}$ Gómez Robledo, 2007, p. XXXIV- XXXVIII.

${ }^{25}$ Vitoria, 2007, pp. 22 у 27.
} 
Como es claro, Vitoria hace referencias constantes a las autoridades teológicas; sin embargo la duda va ganando terreno. La defensa de los nativos, con su herejía, costumbres tal vez caníbales y sus dioses sangrientos, además de la oposición férrea de los conquistadores y los encomenderos que reclamaban sus supuestos derechos, seguramente no fue fácil.

En el caso de la Nueva España, fray Juan de Zumárraga, solicitó al rey, Carlos I, su intervención para que el padre Francisco de Vitoria enviara a la Nueva España a algunos "discípulos sacerdotes de buena vida y ejemplo" para que predicaran en el nuevo mundo. ${ }^{26}$ No fue casual que la solicitud fuera específicamente para el padre Vitoria. Por otra parte, Zumárraga fue un conocido humanista seguidor de Erasmo. En su biblioteca tenía varios libros del de Rotterdam, que es posible suponer se trataba de primeras ediciones. ${ }^{27}$ En el mismo sentido, se puede afirmar que la Doctrina breve de Zumárraga (1543-1544) es un documento notable de la influencia erasmista.

Por su parte, fray Julián Garcés fue dominico de la Orden de Predicadores. Estudió en las universidades de Salamanca y París. A los setenta y cinco años fue nombrado obispo de la primera diócesis que existió en Nueva España, la de Tlaxcala. ${ }^{28}$ Tomó posesión de su sede apostólica el 9 de noviembre de $1529 .{ }^{29}$ En su camino a México se detuvo en la Isla de Santo Domingo, o la Española, como se le conocía en aquella época. Ahí conoció a otros dominicos que también lucharon por los derechos de los nativos del Nuevo Mundo: Antonio de Montesinos $^{30}$ (1480-1540), Tomás de Berlanga (1487-1551) y Bartolomé de las Casas.

\footnotetext{
${ }^{26}$ Gómez Robledo, 2007, p. XX.

${ }^{27}$ Bataillon, 1996, p. 822, nota 62.

${ }^{28}$ Esta distinción a la región de Tlaxcala fue para agradecer el apoyo que se tuvo de los tlaxcaltecas en la toma de Tenochtitlan.

${ }^{29}$ La cédula de nombramiento fue del 6 de septiembre de 1527.

${ }^{30}$ Fray Antonio de Montesinos pronunció en La Española (Santo Domingo) su famoso sermón de adviento en 1511, en que atacó la encomienda y la esclavitud de los nativos de América. A raíz de este sermón se les prohibió a los dominicos predicar en la isla.
} 
Hacia finales de 1536 o principios de 1537, fray Julián Garcés, escribió una carta al papa Paulo III. ${ }^{31}$ La epístola se refirió a los pobladores del Nuevo Mundo y denunció los abusos cometidos contra ellos. Este escrito de Julián Garcés fue motivo para que el papa, Paulo III, tomara una postura clara con respecto a los naturales de América. Garcés atacó a los que sostenían que los indios no eran capaces de entender la nueva fe y los señaló como la voz de Satanás,

"[quien] afligido de que su culto y honra se destruye y es voz que sale de las avarientas gargantas de los cristianos, cuya codicia es tanta, que, por poder hartar su sed, quieren porfiar que las criaturas racionales hechas a imagen de Dios, son bestias y jumentos, no a otro fin de que los que las tienen a cargo no tengan cuidado de liberarlas de las rabiosas manos de su codicia[...]

Son [los indígenas] con justo título racionales, tienen enteros sentidos y cabeza. Sus niños hacen ventaja a los nuestros en el vigor de espíritu y en más dichosa viveza de entendimiento y de sentidos y en todas las obras de manos". ${ }^{32}$

Fray Julián Garcés se vuelca sobre su cariño a los indios y afirma que son mucho más aptos para la confesión y el arrepentimiento. Están dispuestos a dejar a las muchas mujeres que tuvieron durante el paganismo y a restituir sin tardanza lo robado.

Esta misiva tuvo como resultado la bula de Paulo III, Veritas Ipsa, en la cual declara que los indígenas de América, aunque estén fuera de la fe de Cristo, no pueden ser privados de su libertad ni de sus bienes. Además de que deben ser atraídos a la verdadera religión con la palabra divina y el buen ejemplo y no por la fuerza. ${ }^{33}$ Esta bula no es como muchos afirman, la declaración de racionalidad de los indígenas, sino que, como son seres humanos racionales, tienen derecho a sus gobiernos y a sus tierras. Estos comunicados seguramente estuvieron al alcance de Francisco de Vitoria y le sirvieron en sus discusiones en la Universidad de Salamanca. ${ }^{34}$

\footnotetext{
${ }^{31}$ La traducción de la carta al español es la de Genaro García, 1982, pp. 507-518.

32 García, 1982, p. 509 y 510.

${ }^{33}$ García, 1982, Bula de Paulo III, pp. 517 y 518.

${ }^{34}$ Recuérdese que la carta de Garcés al papa fue escrita entre 1536 y 1537 y la primera edición de las Relecciones de Vitoria data de 1557.
} 
Este espíritu de respeto hacia los nativos de las regiones recién conquistadas también alcanzó al rey. Hacia 1543, Carlos I, mandó la "Instrucción que da su majestad para los nuevos descubrimientos" dirigida a fray Juan de Zumárraga, fray Domingo de Betanzos (1480-1549) y fray Juan de la Magdalena. Entre otras cosas el rey apuntó lo siguiente:

"Otro si, habéis de trabajar con las dichas gentes por las mejores vías y maneras lícitas y convenientes que pudieres de traerlos a ellos y a sus pueblos a nuestra amistad y obediencia... guardándoles todos sus privilegios, preeminencias, señoríos, libertades, leyes y costumbres..."35

Frente a los argumentos antes mencionados, parece factible que el encuentro con el Otro, a través de la conquista y la colonización, haya hecho dudar a los teólogos europeos de una racionalidad única emanada de su tradición. Incluso, al referirse a Vitoria y la escuela de Salamanca, Beuchot afirma que resulta comprensible un rechazo al derecho natural:

“La condición humana eminentemente situacional, la circunstancia irrepetible de cada hombre, pone tantas dificultades para captar la unificación en el género humano, que hace dudar de la existencia de una entidad formal, de una especie que unifique a todos los hombres bajo un derecho y sobre todo bajo una obligación común". ${ }^{36}$

En el gráfico 6 se muestra la red de contactos de los misioneros en esta segunda etapa de circulación de actores entre Europa y América.

\footnotetext{
${ }^{35}$ Tormo Sanz, 1980, p. 45.

${ }^{36}$ Beuchot, 1991, pp. 125 y 126.
} 


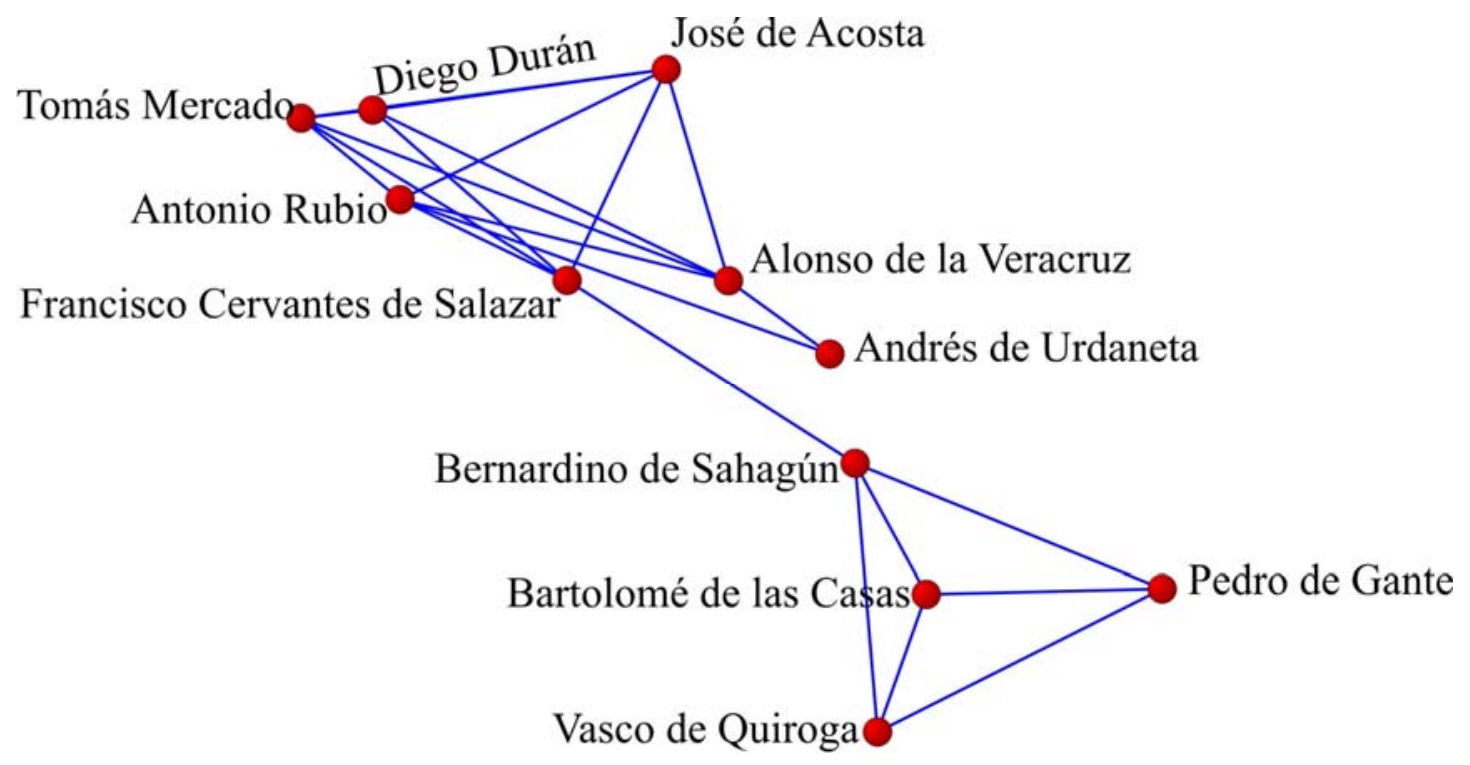

Gráfico 7. Segunda red de misioneros en América.

Los antecedentes del probabilismo, en la figura de uno de sus primeros exponentes, Francisco de Vitoria, parecen señalar que el enfrentar la otredad realmente introdujo la duda, la incertidumbre y la noción de riesgo moral.

En el gráfico 8 se muesrta la red de contactos de lo que se considera la segunda generación de probabilistas.

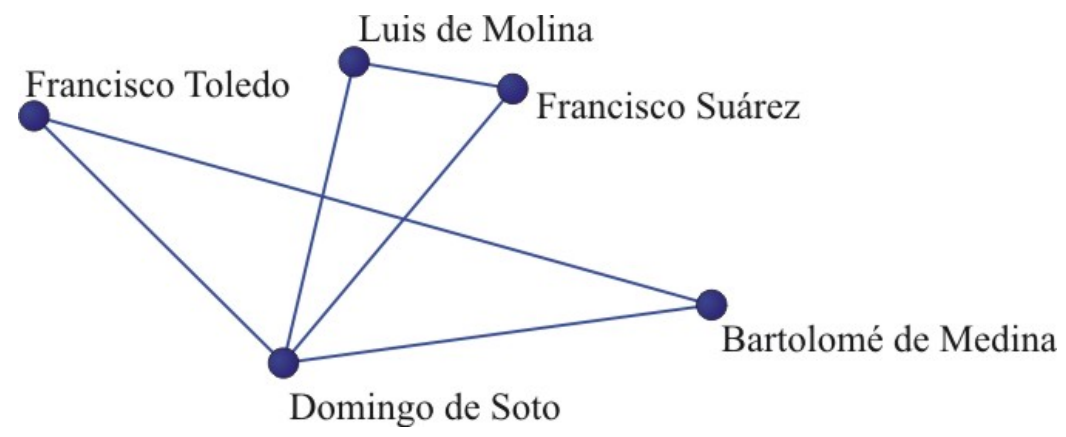

Gráfico 8. Segunda red de probabilistas.

\section{Las misiones del lejano Oriente}

En el siglo XIII, el franciscano Roger Bacon (1220-1292), hizo algunas formulaciones sobre las misiones y las publicó en su PhilosophiaMoralis. En este tratado señaló que 
existía una clara diferencia entre las misiones y las cruzadas. Para Bacon, la argumentación del misionero debe basarse en conceptos universalmente aceptados; se empeñó en establecer un consensusgentiumen en el cual se pudiera armonizar el pensamiento de tártaros, sarracenos, judíos, cristianos, sabios idólatras y paganos. Este misionero propuso como base el ya mencionado consensus formado por la filosofía, la geometría y el juicio escatológico. Para el sabio franciscano había dos formas de demostrar la fe: una de índole divino, en otras palabras los milagros y otra de índole humana, el raciocinio. Para Bacon fue necesario descartar la autoridad de los santos que por principio sería rechazada por los infieles. El método filosófico racional debería estar acompañado de un "procedimiento tomado de la geometría". ${ }^{37}$

En este sentido, los jesuitas fueron los seguidores más apegados a Bacon. Se puede pensar que presentaron ante Europa un abanico de culturas desconocidas, a la mayoría de las cuales se acercaron a través de la filosofía, la educación y particularmente las matemáticas. Instalaron así el germen del relativismo y pusieron en tela de juicio la supuesta superioridad europea, particularmente, al comparar ésta con las culturas del lejano Oriente. ${ }^{38}$

Debemos considerar que, entre las primeras generaciones de misioneros que llegaron a América y los primeros jesuitas en Oriente, pasaron más de treinta años. Durante ese tiempo se dieron los duros debates sobre la guerra justa y los derechos de los nativos. Además de que Vitoria, y varios de los miembros de la Universidad de Salamanca, estaban discutiendo los nacientes principios del probabilismo.

Francisco Javier (1506-1552), primer misionero jesuita, salió para Oriente en 1541, antes incluso de que la Compañía de Jesús tuviera el reconocimiento oficial. Los otros misioneros importantes como Alesssandro Valignano (1539-1606), Mateo Ricci (15521610) y Roberto di Nobili (1577-1656) fueron varias generaciones después, hacia fines del siglo XVI y principios del XVII. También fue esta la época en que Asia subyugó la imaginación de los misioneros: un lugar con culturas superiores, en el que no era

\footnotetext{
${ }^{37}$ Morales, “De la utopía a la locura”, 2008, pp. 62 y 63

${ }^{38}$ Aparentemente la cristiandad occidental había tenido contactos con Mongolia y Pekín a mediados del siglo XIII. Giovanni di Monte Corvino (1246-1328), fue el primer arzobispo del Pekín mongol, llamado entonces Janbalik. En aquella época, lo que intentaron los europeos fue obtener alianzas contra el Islam. Gernet, 2005, p. 402. También, Dunne, 1962.
} 
posible ejercer una guerra -justa o no- y que tenían un amplio conocimiento de las matemáticas y de otras artes y ciencias.

No obstante la grandeza de China, hubo algunos personajes que justificaron la guerra justa, incluso en el caso de las desarrolladas comunidades orientales. Los españoles llegaron a las costas del archipiélago de las islas Filipinas hacia 1565. Desde el principio hubo grandes tensiones entre los misioneros y los encomenderos, al grado que los sacerdotes agustinos, que fueron los primeros en llegar, amenazaron con abandonar las Filipinas. A los agustinos se les respetaba mucho, pues entre otras cosas llegaron encabezados por la figura emblemática del fraile navegante: Andrés de Urdaneta. ${ }^{39} \mathrm{Si}$ esta orden abandonaba las islas, podía significar el desamparo de la presencia hispana, ya que la empresa se quedaría sin justificación misionera.

Una década después de la llegada de los españoles a Filipinas, el gobernador Francisco Sande (1540-1627) propuso a Felipe II un proyecto de invasión militar a China. Sin embargo; el rey contestó el 29 de abril de 1577:

“En cuanto a conquistar la China que os parece se debería hacer desde luego, acá ha parecido que por ahora no conviene se trate de ello, sino que se procure con los chinos buena amistad; y que no os hagáis, ni acompañéis con los corsarios enemigos de los dichos chinos, ni deis ocasión, para que tengan justa indignación con los nuestros". 40

Sin embargo, los planes por conquistar China siguieron. Las ocupaciones de México y Perú llevadas a cabo por un pequeño número de soldados españoles, hacía pensar que la caída del imperio chino podía ser algo similar. Los personajes que presentaron proyectos de colonización hicieron gala de optimismo y confianza. Por otra parte, suponían que podían contar con la ayuda de los japoneses, además de piratas y filibusteros de varias nacionalidades, incluyendo a los propios chinos. De hecho se

\footnotetext{
39 Ollé, Manuel, 2002, p. 31. Véase también Mariano Cuevas, 1943. Recuérdese que fray Andrés de Urdaneta fue quien descubrió el tornaviaje, o la manera de regresar de Filipinas a América por el Pacífico, esto después de la pérdida de varias expediciones que lo intentaron. En términos muy generales, lo que hizo Urdaneta fue subir casi hasta el Japón y aprovechar las corrientes marítimas. Llegó a California y fue costeando hasta llegar a Acapulco. Sus mapas, mediciones y observaciones astronómicas fueron de gran ayuda en la navegación. Véase Mayer, 2012.

${ }^{40}$ Citado por Tormo Sanz, 1980, p. 56.
} 
tomaron algunas medidas suponiendo una invasión militar. Por ejemplo, en 1587, se iniciaron las obras de amurallamiento de la ciudad de Manila y comenzó a reunirse material bélico. Además, entre los planes de invasión, pensaron que podrían contar con el apoyo de los misioneros jesuitas que ya residían en Zhaoqing desde 1583. Estimaron que Ricci, y su grupo de misioneros, darían al ejército invasor español los datos estratégicos que sobre China hubiera recogido.

El caso más interesante de planeación de una invasión militar a China fue el que planteó el padre jesuita Alonso Sánchez (1547-1593) ${ }^{41}$. Este singular personaje estuvo, desde 1581 y hasta 1586, involucrado en las discusiones y comitivas que en Filipinas estudiaron el proyecto de invasión. Además de que actuó como impulsor de las diferentes juntas de discusión, redactor del proyecto y encargado de llevar las propuestas a Felipe II. ${ }^{42}$ Salió de Filipinas con rumbo a la Nueva España el 28 de junio de 1586, sin embargo, al llegar a la ciudad de México, fue detenido por el provincial de la Compañía en Nueva España, Antonio de Mendoza.

Alessandro Valignano (1539-1606) conoció a Alonso Sánchez y sus proyectos bélicos en Oriente. Éste informó al general de la Compañía, Claudio Acquaviva, sobre los intereses que movían a Sánchez y la manera en que se ponían en riesgo las misiones jesuitas en China, que parecían cada día más exitosas. Para evitar un enfrentamiento con Felipe II, pero a la vez salvar las misiones, Acquaviva encontró una tercera vía: nombró como supervisor de Sánchez al padre José de Acosta (1540-1600). En una carta fechada el 2 de julio de 1587 el provincial le comunicó:

“Y para que en todo se vaya con toda edificación y buen modo me ha parecido dar a V.R. por superior inmediato, allende que lo serán los provinciales y Rectores o Prepósitos, según el modo de la Compañía, al P. José de Acosta, con el cual, V.R. consultará lo que hubiese de tratar así con S.M. como con cualesquiera otros, y en todo se seguirá su orden y parecer...". ${ }^{43}$

Acosta, quien ya era un naturalista, teólogo e historiador ampliamente conocido, se encontró con Sánchez en la ciudad de México en 1587. La empresa bélica ya estaba

\footnotetext{
${ }^{41}$ No tenemos datos biográficos sobre Alonso Sánchez.

${ }^{42}$ Un excelente trabajo sobre estos episodios es el de Manuel Ollé, 2002.

${ }^{43}$ Citado por Ollé, 2002, p. 185.
} 
claramente desautorizada por la Compañía de Jesús. Además, el padre Acosta escribió un tratado refutando los cuatro títulos de la propuesta de conquista de China. La argumentación de Acosta estuvo basada en el pensamiento jurídico-teológico de Francisco de Vitoria. De hecho, los tratados de Acosta se consideran dentro de los desarrollos tardíos de la escuela de Salamanca. ${ }^{44}$ Por otra parte, Acosta apuntó que debería considerarse la diversidad étnica y cultural de los infieles que se quería cristianizar, para de esa manera definir el método misional más adecuado, todo esto dentro de los principios de la acomodación y del probabilismo.

Finalmente Sánchez pudo salir de Nueva España, pero acompañado por el padre Acosta. Por su parte, Felipe II dio audiencia a Sánchez en diciembre de 1587. No obstante, en esta reunión siempre estuvo presente Acosta, quien moderó las pretensiones de su compañero. Sin embargo, Alonso Sánchez entregó en secreto un memorial al rey. ${ }^{45}$ Los intentos de Sánchez tuvieron acogida por Felipe II, quien en marzo de 1588 ordenó la constitución de una junta para debatir las propuestas de la conquista de China, pero la empresa de Sánchez estaba condena a malograrse. Todos sus esfuerzos coincidieron con el estrepitoso fracaso de la Armada Invencible en agosto de 1588. Este hecho convirtió en inviable el proyecto de conquista de la China.

Como hemos podido ver, las negativas de Felipe II para invadir China no fueron sistemáticas, ni a priori, sino el resultado de la negativa del general de los jesuitas y, principalmente, de la difícil situación militar del monarca español en Europa.

Las misiones en el lejano Oriente, ya fuera que llegaran por Filipinas o por Macao, siguieron causando revuelo en Europa. Desde finales del siglo XVI y durante todo el XVII, los países del Lejano Oriente cautivaron la mente de los misioneros y, en general, de los europeos cultos. Un ejemplo es el del franciscano Juan de Zumárraga, quien hacia el año de 1545, escribió una carta al príncipe de España, quien después sería Felipe II, en la que le manifestó su proyecto para, a sus setenta años, seguir de misionero pero ahora en China. Zumárraga obtuvo el permiso real, pero no así el papal, por lo que siguió siendo obispo de México hasta su muerte. ${ }^{46}$

\footnotetext{
${ }^{44}$ Ollé, 2002, p. 188 y ss. Véase también O’Gorman, 2006 y Morales, 2008.

45 Ollé, 2002, p. 199.

${ }^{46}$ Morales, 2008, p. 69.
} 
Desde que Francisco Javier arribó a India en 1542, la Compañía de Jesús formó la vanguardia de las misiones portuguesas, que a su vez fueron las más significativas en Oriente. Los jesuitas desarrollaron un sistema de comunicación que fue instalado por I gnacio de Loyola (1491-1556) desde la creación de la orden. Entre los miembros de la Compañía debería existir un estrecho contacto con los superiores y los otros hermanos, razón por lo que se deberían mandar informes por lo menos una vez al año desde las misiones. ${ }^{47}$ Además, empezaron a escribir constantemente a los superiores directos, a otros miembros de la Compañía y también cartas dirigidas al público en su conjunto. Las epístolas viajaban de hogar en hogar y fueron copiadas en las residencias jesuitas. Éstas se leían a la hora de las comidas. También se tradujeron y enviaron a familiares o benefactores. Por ejemplo, una carta de Francisco Javier del 15 de enero de 1544, escrita desde Cochín fue impresa en París un año después. ${ }^{48}$

En el gráfico 9 se muestra la red de cotactos de los misioneros en oriente hacia 1565, de la que forma parte Domingo de Salzar, uno de los iniciadores del probabilismo en la Universidad de Salamanca.

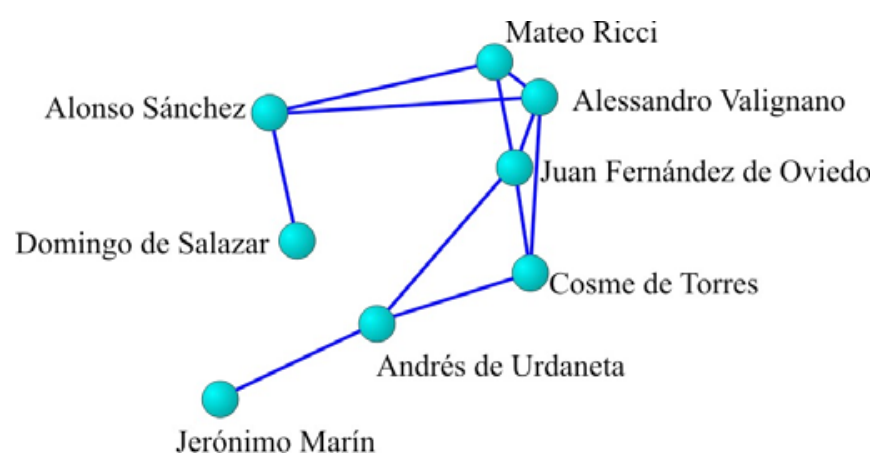

Gráfico 9. Red de misioneros en Oriente 1565.

Durante los siglos XVI y XVII, y como vimos en el caso de la Nueva España, las cartas fueron la forma de comunicación más importante. Éstas fueron esperadas con impaciencia en las cortes reales, en las universidades y en los hogares. Por ejemplo, el

\footnotetext{
${ }^{47}$ Aunque la costumbre epistolar fue generalizada entre las diferentes ordenes religiosas, los jesuitas la convirtieron en una obligación. Las cartas sirvieron para apoyar y edificar las misiones, pero también tuvieron otras funciones, particularmente a partir del siglo XVIII. Según Zermeño, 2008, los misioneros también actuaron como corresponsales científicos en varios lugares lejanos a Europa.

${ }^{48}$ Correia-Alfonso, 1980, pp. 60-61.
} 
importante misionero en Brasil, Manuel da Nóbrega (1517-1570), escribió a Lisboa, de ahí las cartas fueron enviadas a Roma y se hicieron copias de ellas y se distribuyeron por Europa e India.

"Las cartas que vinieron de Portugal, tanto de su colegio como de Brasil, en el año 52, nos llenaron sobremanera de alegría y despertaron mucho fervor. La noche en que llegaron, luego de tocada la campana, fueron leídas hasta la una de la madrugada y en el refectorio los diez días siguientes. E inmediatamente, un resumen de ellas fue copiado, y fueron enviadas a China, Japón, las Malucas y Malaca y a todos los otros lugares donde se encuentran nuestros Padres. Y si usted supiera, queridísimo, cómo resuenan aquí las noticias que provienen de allí y de qué forma la gente, aparte de los hermanos, las desea y codicia y cuántas reliquias se han hecho con sus cartas, creo sin duda que ustedes se ofrecerían a cualquier prueba corporal con tal de brindar a sus hermanos aquí, tal recreación placentera". ${ }^{49}$

La costumbre epistolar se complementó con otras formas edificantes como los manuscritos, los impresos y las imágenes. Particularmente estas últimas fueron muy utilizadas en las misiones, aunque variaron dependiendo del caso. En América las imágenes de la pasión fueron las más socorridas, en Oriente las de la virgen y el niño. Todas tenían la intensión de influir sobre los sentimientos de los convertidos.

Tanto Brasil como México fueron lugares de paso para llegar al lejano Oriente. Una de las rutas de Portugal paraba en Bahía, Brasil, para después salir a Goa en la India. La de España iba hacia Nueva España, al puerto de Acapulco y posteriormente a las Islas Filipinas. Aunque hubo otras rutas, estas fueron algunas de las más frecuentadas.

Pero las misiones en Oriente fueron mucho más difíciles que en América. Aunque llegaron a percibir la grandeza de China, nunca imaginaron que se encontraban en un territorio inmenso, con una población de más de 150 millones de habitantes y elites con cultura sofisticada y compleja. ${ }^{50}$ La expansión de rutas marítimas de españoles y portugueses estuvo infiltrada por la piratería que afectó seriamente el antiguo

\footnotetext{
${ }^{49}$ Citado por Correia-Alfonso, 1980, p. 63.

${ }^{50}$ Corsi, 2008 a.
} 
comercio oriental entre China, Japón, Filipinas e Indonesia. ${ }^{51}$ No es difícil imaginar la desconfianza que inspiraron los misioneros europeos y los estrictos controles que se dieron con respecto a ellos. Por estas razones es que Francisco J avier no pudo entrar nunca a China y murió cerca de Cantón en 1552.

Francisco Javier no solo fue el primer misionero jesuita, sino que estuvo en muchos lugares de Asia. Después de varios años de experiencia misionera en la India, desembarcó en Japón el 15 de agosto de 1549. La primera expedición a Japón estuvo formada por españoles, entre otros Cosme de Torres - quien había sido capellán del virrey de la Nueva España- y Juan Fernández de Oviedo.

Como apunta Lizón Tolosana:

“Japón es un país extrañamente fascinante y turbador; al poner el pie en el suelo nipón se enfrenta, a pesar de su información, a lo extraño, al Otro con el que no está familiarizado y que, por lo tanto, requiere atención, intercambio, diálogo verbal e interpretación". ${ }^{52}$

En un primer momento, Francisco Javier, se admiró de la cultura y conocimiento de los habitantes del Japón, particularmente de los bonzos, pero pronto encontró algo que chocó con su condición de sacerdote: "el abominable pecado de los bonzos [...] con los mozos que enseñan a leer y escribir". ${ }^{53}$ No se explica que gente tan racional cometa actos contra natura, según su propia clasificación cultural. Dentro de su impacto, buscó explicaciones culturales.

“De dos cosas me espanté mucho en esta tierra, [...] los bonzos son inclinados a pecados que natura aborrece y ellos lo confiezan y no lo niegan [...]"54

El segundo punto que le preocupó fue cómo personas dedicadas a la meditación, como los bonzos, piensen que tan abominable pecado no tiene importancia. Además fue algo tan público y manifiesto entre toda la población, ya fueran hombres, mujeres, adultos o personas jóvenes, que le sorprendió que lo vieran con tanta naturalidad. Aunque la

\footnotetext{
${ }^{51}$ Gernet, 2005, p. 402.

52 Lizón Tolosana, 2005, p. 13.

${ }^{53}$ Lizón Tolosana, 2005, p. 19.

${ }^{54}$ Lizón Tolosana, 2005, p. 20.
} 
sodomía cuestionó la concepción escolástica de la naturaleza humana, Francisco Javier pensó en una razón cultural para explicar el hecho. Para él fue una práctica que adquirieron desde tiempos remotos y los demás japoneses la siguieron por costumbre. Esta conducta moral, en aquella época, fue férreamente castigada en Europa. Por ejemplo, en España, la homosexualidad se castigaba con pena de muerte. Seguramente para el misionero no fue fácil buscar una explicación cultural a lo que consideraba un problema moral, pero la presencia del Otro lo obligó a encontrar una disculpa, a pesar de que la aceptación social de la sodomía cuestionaba la concepción escolástica de la naturaleza humana. Sin embargo, Francisco J avier insiste en conocer los monasterios y discutir con sus monjes. Al respecto, él mismo dice:

“Con algunos de los más sabios hablé muchas veces [...] principalmente con uno a quien todos [...] tienen mucho acatamiento, así por sus letras, vida y dignidad [...] que es de ochenta años, y se llama Ninxit [...] Es entre ellos como obispo [...] en muchas pláticas que tuvimos, lo halle dudoso y no saberse determinar si nuestra alma es inmortal o si muere juntamente con el cuerpo [... $]^{\prime \prime 5}$

Estas largas conversaciones entre dos sabios, pero de culturas tan diferentes, debieron ser fascinantes. Como se puede ver, la duda no solo acoge al jesuita, el anciano monje también vacila ante la otredad.

Mateo Ricci perteneció al primer grupo de misioneros que logró instalarse en China. Llegó a Macao en 1582 y en 1598 alcanzó a residir tres meses en Pekín. Se estableció definitivamente en esta ciudad en 1601. Los primeros misioneros a los que se les permitió entrar en China, tuvieron un conocimiento muy limitado de lo que el gran Imperio del Lejano Oriente era en aquella época. En el gráfico 10 se muestra la red de contactos de los misioneros en China, recordemos que Mateo Ricci es el gran promotor del porbabilismo en el Colegio Romano.

${ }^{55}$ Lizón Tolosana, 2005, p. 24. 


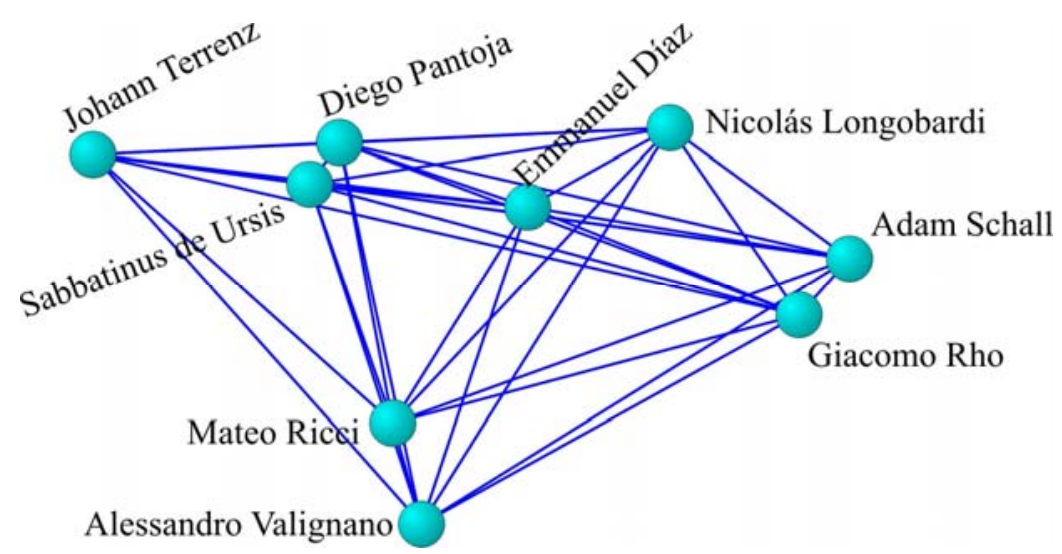

Gráfico 10. Red de misioneros en China.

Los problemas y malos entendidos entre los jesuitas y los chinos, en general, fueron múltiples. En 1589 fueron expulsados de Zhaoquing por mandarines hostiles y hacia 1592 fueron nuevamente atacados. Pero uno de los malentendidos más significativos fue el ocurrido en 1600. Ricci llevaba en su equipaje personal un crucifijo que, según su propia descripción, era pequeño pero intensamente real, -como fueron las esculturas sagradas a finales del siglo XVI-, tallado en madera y con la sangre pintada para que causara la impresión más profunda. Este objeto religioso fue descubierto por el eunuco MaTang quien pensó que era una cosa de magia negra. Se organizó tal escándalo, que fue necesaria la presencia del ejército y el equipaje de los jesuitas fue revisado de arriba abajo, en busca de más objetos que revelaran la maldad de los misioneros. Además de que se les amenazó con darles palizas brutales si no entregaban esas cosas repugnantes. Ricci no pudo dar una explicación satisfactoria del significado de la crucifixión: por un lado no pudo decir que esa era la imagen del Dios que querían propagar por China y por otra parte se dio cuenta del horror que había causado la crueldad que reflejaba la imagen. Los amigos chinos de los jesuitas, les recomendaron que "redujeran a polvo los demás crucifijos que tuvieran consigo para que no quedara ningún recuerdo de ellos". Ante un rechazo tan hostil, Ricci y su grupo, decidieron dar mayor preeminencia a las imágenes de la Virgen y el Niño, iconografía que gustaba mucho a la mayoría de los chinos. ${ }^{56}$

${ }^{56}$ Spence, 2002, p. 244. 
Pocos años antes y desde Macao, Alessandro Valignano, solicitó al general de la Compañía, que le enviara una serie de objetos y libros para poder regalar al emperador de China. No obstante acotó las características que deberían tener:

"Asimismo harían venir otros libros de caras y otras figuras hermosas muy ricamente iluminadas, las cuales sean todas de caras alegres, y no de martirios, ni de guerras, ni los misterios de la pasión de N. S., porque por ahora no sirven ..." 57

Esta necesidad de no mostrar los misterios de la pasión de Cristo a los chinos, fue parte de los más crudos debates y rechazo de los jansenistas a los jesuitas.

Otro de los mal entendidos que se dio en aquellas regiones fue que el grupo de misioneros que llegó a Oriente junto con Ricci fueron confundidos, en un primer momento, con monjes budistas. El budismo, que también es una religión de salvación, presentaba varias similitudes con el cristianismo. Estas analogías lograron numerosas conversiones de campesinos chinos. No obstante, los jesuitas pronto se dieron cuenta de que el budismo era mal visto por las elites chinas que, en aquellas circunstancias, consideraron al cristianismo como una variante del budismo que regresaba a China después de haber conquistado a los bárbaros de Occidente. ${ }^{58}$

Para contrarrestar el rechazo de los grupos de poder, hacia 1594, los jesuitas adoptaron los trajes y los modales de los letrados chinos. Además hicieron alarde de sus conocimientos de matemáticas, astronomía, cartografía y llevaron maquinas occidentales como: relojes, telescopios e instrumentos de observación astronómica. Asi mismo, fueron muy importantes los tratados de mnemotécnica. En 1596, Ricci escribió el borrador de su trabajo sobre las artes mnemotécnicas. ${ }^{59}$

En 1607 se publicó en Pekín la traducción al chino de los seis primeros libros de los Elementos de Euclides, llevada a cabo por el propio Ricci en colaboración con el intelectual y experto en agronomía chino XuGuangqi (1562-1633) ${ }^{60}$. Ricci murió en 1610 en Pekín siendo muy apreciado por las elites intelectuales de aquella ciudad.

\footnotetext{
${ }^{57}$ Citado por Corsi, 2008a, p. 85. El subrayado es nuestro.

${ }^{58}$ Gernet, 2005, p. 404.

${ }^{59}$ Spence, 2002, p. 268.

${ }^{60}$ Cervera Jiménez, 2008, p. 159.
} 
Poco después de la muerte de Ricci, astrónomos y matemáticos jesuitas como Johann Terrenz (1576-1630), Giacomo Rho (1592-1638) y Johann Adam Schall (1591-1666) hicieron las traducciones de libros europeos de matemáticas y astronomía al chino. En particular, Terrenz, fue amigo de Galileo y cuando salió para China llevó con él un telescopio e hizo algunas traducciones de obras de Galileo al chino. También, estos misioneros, ayudaron en la reforma del calendario lo que les llevó, durante todo el siglo XVII, a un reconocimiento constante de su prestigio en la corte Ming de Pekín. Finalmente, en 1692 ya con la dinastía Qing, los jesuitas lograron el edicto de libertad de predicación que era lo que habían estado esperando durante décadas. ${ }^{61}$

Como ya señalamos, quizás el proyecto científico chino más significativo en el que participaron los misioneros fue la reforma del calendario. Sin embargo, en 1612 el proyecto fue abandonado. No obstante, hacia 1630, el chino convertido al cristianismo, XuGuangqi, al que ya mencionamos, y que fue colaborador de Ricci, y quien fuera vicepresidente del tribunal de ritos, dio su apoyó para que se reviviera el antiguo proyecto de actualizar el calendario chino. ${ }^{62}$ La oportunidad llegó el 21 de junio de 1629 en que ocurrió un eclipse de sol. Se organizó una especie de competencia entre las tres escuelas astronómicas que existían: la tradicional china, la musulmana que había sido fundada varios siglos antes y la europea. Los cálculos, según los métodos europeos, fueron llevados a cabo por el jesuita Terrenz $y$, finalmente, fueron mucho más atinados que los de las otras escuelas. El emperador pidió una explicación de los errores de los chinos y los musulmanes y tras un examen minucioso, se vio que no había errores en los cálculos, por lo que quedó patente que sus sistemas eran bastante imprecisos, pues los errores se habían acumulado a lo largo del tiempo. Se acordó que la única solución era reformar el calendario totalmente. ${ }^{63} \mathrm{El}$ modelo astronómico que se utilizó fue el de TychoBrahe (1546-1601), corriente que siguieron los jesuitas en todo el mundo.

Algunos autores han apuntado la influencia hermética en los padres que fueron a China. Uno de los elementos más significativos es, sin lugar a dudas, los problemas

\footnotetext{
${ }^{61}$ Cervera Jiménez, 2008, p. 159.

${ }^{62}$ Muchos estudios han analizado este problema de la competencia entre las diferentes escuelas de matemáticas. Dunne, 1962 y Cervera, 2001, entre otros.

${ }^{63}$ Cervera Jiménez, 2008, p. 161.
} 
mnemotécnicos. El arte de la memoria, como bien ha señalado Francis Yates, fue uno de los conocimientos claves de las corrientes herméticas europeas, desde la época de Marsilio Ficino (1433-1499). Quizás uno de los últimos herméticos, pero que tuvo una importancia capital a nivel mundial, fue Athanasius Kircher (1602-1680). Este autor recreó las vivencias chinas de las misiones jesuitas, las ilustró de manera magistral y su lectura fue obligada para los intelectuales de fines del siglo XVII. Baste como ejemplo recordar los libros de Sor Juana Inés de la Cruz (1651-1695) en México. ${ }^{64}$

Otro de los misioneros jesuitas que causó gran revuelo en Europa fue Roberto di Nobili (1572-1656), quien llegó al sur de la India en 1605 y vivió como misionero durante cuarenta años en Madura. Al igual que Ricci en la China, Nobili adoptó la vestimenta de los brahmanes, sus costumbres alimenticias y las formas culturales. Se presentó como un noble romano, lo cual sí había sido, pero que renunció a las vanidades de la vida. En términos de la India, Nobili fue un sannyasi. Solo comía una vez al día y su dieta consistía en: arroz, leche, hierbas y agua. Su vestimenta fue una bata amarilla, un velo rojo o blanco sobre la espalda, una toca en la cabeza en forma de turbante y sandalias de madera de cinco centímetros de altura. También llevó los cinco cordones que los brahmanes utilizaban en el cuello: tres de oro y dos de plata. Para Nobili, los primeros simbolizaban a la Santísima Trinidad y los segundos el cuerpo y el alma del Redentor. Colgado a los cordones llevaba una cruz. Su forma de vestir no fue indiferente para quienes recibieron noticias de esto, tanto en Europa, como en la América ya del siglo XVII. Pero, tal vez lo más importante en su proceso de adaptación fue el estudio del Hinduismo y el dominio del Tamil en el que escribió trabajos relevantes, entre otros, Diálogo en la vida eterna. Éste es un texto escrito en forma de conversación entre un maestro, gurú y su discípulo, sisya. En este diálogo presenta algunos principios morales e introduce elementos teológicos tomistas, pero totalmente adaptados al contexto cultural y religioso del sur de la India. ${ }^{65}$

Las misiones en China y la India provocaron las terribles discusiones sobre los ritos chinos y malabares. Como hemos visto a lo largo de este apartado, los misioneros

\footnotetext{
${ }^{64}$ Aparentemente Sor Juana tenía en su biblioteca varios libros de Kircher. En el famoso retrato que Cabrera hizo de la monja, los libros que se encuentran detrás de ella son de este autor. Además de que así lo señalan varios de sus biógrafos.

${ }^{65}$ Clooney, 1999, p. 402.
} 
jesuitas aceptaron una conversión dulce, que tendió a no perturbar, ni poner en crisis las costumbres y tradiciones locales. Con esta política de tolerancia, hacia $1700 \mathrm{se}$ consideró que los chinos convertidos al cristianismo sumaban cerca de quinientos mil.

Pero este trabajo espiritual de tolerancia introdujo dos aspectos terriblemente polémicos para las mentalidades rigoristas europeas. Por un lado la aceptación de Confucio. Este brillante filósofo chino era reconocido y honrado casi como un santo. Los jesuitas apuntaron que este no era un culto religioso, sino de carácter totalmente civil. Ricci insistió en que había concordancia entre el confucianismo y el cristianismo y consideró que los escritos de Confucio constituían un sistema de ética social y de moral individual. No obstante, la manera en que los chinos reconocían a Confucio fue en una especie de templos casi sagrados, lo que hizo pensar en Europa que los jesuitas estaban aceptando la idolatría. En segundo lugar, estuvo una tradición china muy importante: el culto a los antepasados, ésta se tomó también como una forma de idolatría.

En el caso de la India, Nobili aceptó que los conversos brahmanes utilizaran ciertos símbolos que dentro de su casta eran importantes. Algunos de ellos fueron, por ejemplo, el "Cordón". Como ya señalamos, los individuos de casta alta solían llevar en el cuello tres o cinco listones y, los convertidos al cristianismo, colgaron a estos listones un crucifijo o bien una medalla. El sacerdote cristiano la bendecía de la misma manera en que se bendicen los escapularios. Los brahmanes también acostumbraban tomar baños rituales en público, como una obligación de su casta. Nobili los permitió, lo mismo que algunos objetos rituales en los matrimonios de los convertidos al cristianismo.

Estas adaptaciones o procesos de aculturación causaron gran revuelo en Europa. Hacia 1621, el papa Paulo V, permitió oficiar la misa en chino y adaptarse a los ritos confucianos, lo que pareció favorecer a los misioneros. Pero, posteriormente, estos ritos fueron condenados por el Vaticano y se convirtieron en temas de ataque y acusación de probabilismo y moral laxa.

Las misiones en Oriente contrastaron con las americanas. Como hemos visto, los primeros misioneros en Nueva España abrieron los procesos de incertidumbre y las preguntas ante la otredad. Además de introducir las discusiones y grandes debates sobre los derechos de los no europeos. Las misiones en Oriente ya habían pasado por el tamiz de las discusiones misioneras en América. Particularmente las misiones 
jesuitas de finales del XVI y de todo el siglo XVII, tuvieron la posibilidad de adaptarse a las culturas de los otros. En ese período, el probabilismo ya había invadido la teología moral. Francisco Suárez y Luis de Molina habían introducido sus ideas y habían marcado un cambio y la aceptación plena del probabilismo en la teología moral y, por consiguiente, en las actitudes de los misioneros ante las culturas lejanas a la mediterránea. No obstante, todos estos cambios, crearon tensiones muy fuertes en Europa. El primer momento de apertura ante el descubrimiento de América había pasado y las corrientes rigoristas se dejaron sentir nuevamente.

En general, podemos decir, que la reflexión probabilista llevo a poner en tela de juicio la ley natural y dar un valor creciente a la conciencia individual. Estos elementos fueron y son necesarios para enfrentar la otredad, el valor del Otro en su persona y su cultura.

En el gráfico 11 se mustra la red de contactos entre los probabilistas y los misioneros en América y en Oriente, en la que se puede constatar el contacto de los probabilistas con los misioneros tanto en América como en Oriente en una red conexa, en ella se destaca el papel que tuvieron pensonajes como Francisco de Vitoria (probabilista), Bernandino de Sahagún (misionero en América) y Mateo Ricci (misionero en oriente), quienes tuvieron los valores más altos de intermediación y cercanía ${ }^{66}$.

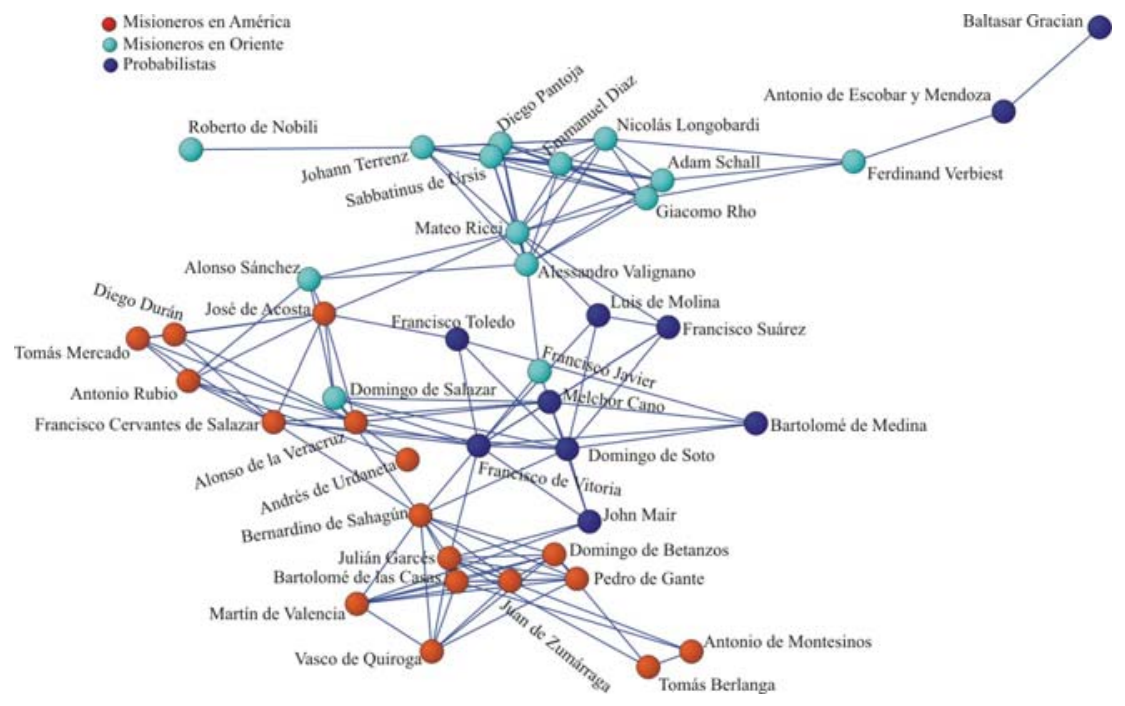

Gráfico 11. Red de misioneros en América, probabilistas y misioneros en Oriente.

\footnotetext{
${ }^{66}$ En el enlace siguiente se muestra la circulación de personajes y las redes de contactos: http://revista-redes.rediris. es/webredes/novedades/red_probabilismo.htm
} 


\section{Consideraciones finales}

Aunque hubo ciertos antecedentes de la probabilidad en épocas remotas, podemos decir que muchos de los autores que han escrito sobre la historia de esta ciencia insisten en afirmar que nació en el siglo XVII. Sin embargo, aunque dan muchas razones de diferentes tipos, el rompecabezas no acaba de quedar claro. Dentro de este bricolage de ideas sobre la génesis de la probabilidad agregamos un nuevo elemento: el descubrimiento de América y su posterior colonización, que presentó ante una Europa cerrada un mundo de diversidad cultural.

Como hemos señalado, la otredad causó muchos sentimientos, desde el horror hasta la comprensión del Otro. Sin embargo, también fue inevitable que introdujera la duda, la incertidumbre y la noción de riesgo moral. Que se creara un principio moral como el probabilismo que se abrió a la lógica y la racionalidad de otras culturas. Como también fue inevitable una contrarreacción rigorista que justificara las acciones y creencias europeas.

Efectivamente, la idea de probabilidad - tan importante para la ciencia actual- es multicausal, como la mayoría de las grandes corrientes de pensamiento. En este caso concreto, el de la probabilidad, es necesario recurrir a un contexto sociocultural muy particular: lo que sucedió en el siglo XVI con la expansión europea, tanto en el continente americano como en el lejano Oriente. El problema de enfrentar, juzgar y convivir con el Otro.

Los contactos entre personajes, visualizados a través de las redes, nos han permitido divisar lo invisible. Hemos podido seguir a los hombres y sus escuelas de pensamiento. Desde la red de misioneros que comenzó a conformarse en la Universidad de Salamanca, hasta la red más grande y compleja que comprende los misioneros en América, los probabilistas y los misioneros en Oriente, pasando por varias gráficas que nos han permitido seguir a estos interesantes personajes en su peregrinar, ya sea por el mundo físico, como por el pensamiento.

Las redes nos han permitido ir más allá de los marcos institucionales. A través de la metodología de redes hemos podido visualizar la circulación de personajes y conocimientos en el siglo XVI y principios del XVII. Las redes nos han permitido seguir el relato histórico y sus complejos planos superpuestos. 
Como vimos, en los albores del siglo XVI arribaron a América los primeros misioneros. Durante esta etapa se plantearon las dudas ante el Otro y sus derechos, además se desarrollaron en Europa las primeras pautas del probabilismo. Como vimos a lo largo de este trabajo, los autores de esta corriente estuvieron muy ligados a las noticias y personajes que llegaban de América. Cuando los primeros misioneros tocaron al lejano Oriente, el probabilismo había madurado en las discusiones universitarias. Al enfrentar culturas más desarrolladas que las americanas, los misioneros estaban más preparados ideológica y moralmente para convivir con ellos. El siglo XVI implicó un momento de apertura para Europa, no obstante, el XVII volvió a cerrarse. Las corrientes rigoristas ganaron terreno. Sin embargo, a pesar de esta reacción, las ideas de incertidumbre y riesgo moral ya habían ganado un lugar en el pensamiento.

\section{Referencias bibliográficas}

Acosta, J. (2006). Historia natural y moral de las Indias. México: Fondo de Cultura Económica.

Aguirre Beltrán, G. (1970). El proceso de aculturación en México. México: Universidad Iberoamericana.

Bataillon, M. (1996). Erasmo y España. México: Fondo de Cultura Económica.

Bergin, J. (Ed.) (2002). El siglo XVII. Historia de Europa Oxford. Barcelona, España: Crítica.

Bernard, C. y Gruzinski, S. (1992). De la idolatría. Una arqueología de las ciencias religiosas. México: Fondo de Cultura Económica.

Bertrand, M. y Lemercier, G. (2011). Introducción: ¿en qué punto se encuentra el análisis de redes en Historia?, Revista Redes, 21 (1), 33-41.

Beuchot, M. (1991). Estudios de historia y de filosofía en el México colonial. México: Universidad Nacional Autónoma de México. Instituto de Investigaciones Bibliográficas.

Brockliss, L. W.B. (2002). La era de la curiosidad. En Joseph Bergin Bergin (Ed.). El siglo XVII. Historia de Europa Oxford (pp. 161-200), Barcelona, España: Crítica.

Caro Baroja, J. (1978). Las formas complejas de la vida religiosa. (Religión, sociedad y carácter en la España de los siglos XVI y XVII). Madrid, España: Akal. 
Cervera Jiménez, J. A. (2008). Giacomo Rho, S.J., y su obra matemática en chino. En Elisabetta Corsi, Órdenes religiosas entre América y Asia. Ideas para una historia misionera de los espacios coloniales (pp. 157-170). México: El Colegio de México.

Cervera Jiménez, J.A. (2001). Ciencia misionera en Oriente. Los misioneros españoles como vía para los intercambios científicos y culturales entre el estremo Oriente y Europa en los siglos XVI y XVII. Zaragoza, España: Universidad de Zaragoza. (Cuadernos de Historia de la Ciencia, núm. 12)

Chinchilla, P. y Romano, A. (Eds.) (2008). Escrituras de la modernidad. Los jesuitas entre la cultura retórica y cultura científica. México: Universidad I beroamericana.

Clooney, F. X. (1999). Roberto de Nobili's Dialogue on Eternal Life and the Early Jesuit Evaluation of Religion in South India. The Truth-Showing Mirror. J esuit Catechism and the Arts in Mughal India, En John O'Malley, Gauvin Alexander Bailey, Steven Harris y T. Frank Kennedy. (Eds.). The Jesuits. Cultures, Science and the Arts, 1540-1775 (pp. 402-417), Toronto, Canadá: University of Toronto.

Correira-Alfonso, J. (1980). Contactos indo americanos a través de los misioneros jesuitas, En Ernesto de la Torre Villar (Comp.), La expansión hispanoamericana en Asia siglos XVI y XVII (pp. 57-66). México: Fondo de Cultura Económica.

Corsi, E. (2008). Órdenes religiosas entre América y Asia. Ideas para una historia misionera de los espacios coloniales, México, El Colegio de México.

(2008a). La retórica de la imagen visual en la experiencia misional de la Compañía de Jesús en China, En, Perla Chinchilla y Antonella Romano (eds.). Escrituras de la modernidad. Los jesuitas entre la cultura retórica y cultura científica (pp. 69-104), México, Universidad Iberoamericana.

Cuevas, M. (1943). Monje y marino. La vida y los tiempos de fray Andrés de Urdaneta. México: Galatea.

Delumeau, J. (1992). La confesión y el perdón. Las dificultades de la confesión, siglos XIII al XVIII, Madrid, España: Alianza Universidad.

Dunne, G. H. (1962). Generation of Giants: The Story of the Jesuits in China in the lasta Decades of the Ming Dynasty. Indiana, Estados Unidos: University of Notre Dame. 
García, G. (1982). El clero durante la dominación española. Documentos inéditos o muy raros para la historia de México. México: Porrúa. (Biblioteca Porrúa, núm 58. Documéntos inéditos o muy raros para la historia de México)

Gernet, Jacques (2005). El mundo chino. Barcelona, España: Crítica.

Gómez Robledo, A. (2007). Introducción. En Francisco de Vitoria, Relecciones del Estado, de los indios y del derecho de la guerra (pp. I-LXXXI). México: Porrúa. (Colec. "Sepan cuantos...", núm. 261)

Krotz, E. (2004). La otredad cultural entre utopía y ciencia. Un estudio sobre el origen, el desarrollo y la reorientación de la antropología. México: Fondo de Cultura Económica y Universidad Autónoma Metropolitana.

Lisón Tolosana, C. (2005). La fascinación de la diferencia. La adaptación de los jesuitas al Japón de los samuráis, 1549-1592. Madrid, España: Alcal Ediciones.

Mayer Celis, L. (2011). La corriente moral del probabilismo y su influencia en la génesis de las ideas científicas de probabilidad, Estatística e Sociedade, (1), nov, 65-85.

(2012). La circulación de hombres, instrumentos, libros y conocimientos en el siglo XVI. El caso del tornaviaje en el océano Pacífico, QUIPU, 14(2), 173-191.

Morales, F. (2008). De la utopía a la locura. El Asia en la mente de los franciscanos de Nueva España. En Elisabetta Corsi, Órdenes religiosas entre América y Asia. Ideas para una historia misionera de los espacios coloniales, (pp. 57-84). México: El Colegio de México.

O'Gorman, E. (2006). Prólogo, tres apéndices y un índice de materias. En Joseph Acosta, Historia natural y moral de las Indias (pp. XVII-LXXVII). México: Fondo de Cultura Económica.

Ollé, M. (2002). La empresa de China. De la armada invencible al Galeón de Manila. Barcelona, España: Acantilado.

O'Malley, J., Bailey, G. A., Harris, S. y Kennedy, T. F. (Eds.) (1999). The Jesuits. Cultures, Science and the Arts, 1540-1775. Toronto, Canadá: University of Toronto.

Pavone, S. (2007). Los jesuitas desde los orígenes hasta la supresión. Buenos Aires, Libros de la Araucaria. 
Ranke, L. V. (1993). Historia de los Papas. México: Fondo de Cultura Económica.

Rosé, I. (2011). Reconstrucción, representación gráfica y análisis de las redes de poder en la alta edad media. Aproximaciones a las prácticas sociales de la aristocracia a partir del ejemplo de Odón de Cluny (muerto en 942). Revista Redes, 21(5), 139-217.

Spence, J. D. (2002). El palacio de la memoria de MatteoRicci. Un jesuita en la China del siglo XVI. Barcelona, España: Tusquets Editores.

Tormo Sanz, L. (1980). Algunas ideas rectoras de las relaciones entre las indias españolas y los países del extremo oriente durante el siglo XVI. En Ernesto de la Torre Villar (Comp.), La expansión hispanoamericana en Asia siglos XVI y XVII (pp. 38-56). México: Fondo de Cultura Económica.

Torre Villar, E. de la (Comp.) (1980). La expansión hispanoamericana en Asia siglos XVI y XVII. México: Fondo de Cultura Económica.

Vitoria, Francisco de (2007). Relecciones del Estado, de los indios y del derecho de la guerra. México: Porrúa. (Colec. "Sepan cuantos...", núm. 261)

Wallace, W. A. (2004). Domingo de Soto and the Early Galileo: Inglaterra: Ashgate Variorum.

Zermeño, G. (2008). Cartas edificantes y curiosas de algunos misioneros jesuitas del siglo XVIII. Travesías, itinerarios, testimonios. México: Universidad Iberoamericana. 